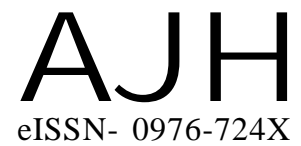

Received : 04.09.2015

Revised : 23.04.2016

Accepted : 03.05.2016

Members of the Research Forum

Associated Authors:

${ }^{1}$ Department of Horticulture, College of Agriculture, Junagadh

Agricultural University, JUNAGADH (GUJARAT) INDIA

Author for correspondence :

SANDEEP SINGH

Department of Horticulture, College

of Agriculture, Junagadh

Agricultural University, JUNAGADH

(GUJARAT) INDIA

Email : brarsingh88@gmail.com
THEASIAN JOURNAL OF HORTICULTURE

Volume 11 Issue 1 June, 2016 | 119-123

Visit us -www.researchjournal.co.in

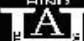

$S$

RESEARCH PAPER

DOI : 10.15740/HAS/TAJH/11.1/119-123

\title{
Effect of pinching on growth of carnation varieties grown under protected condition
}

\section{SANDEEP SINGH, K.M. KARETHA ${ }^{\mathbf{1}}$ AND VIRENDRA SINGH ${ }^{1}$}

ABSTRACT : An experiment was conducted to study the effect of pinching methods on carnation under protected condition. The results of present investigation revealed that variety Rendez-vous $\left(\mathrm{V}_{4}\right)$ recorded significantly the highest plant height $(28.99 \mathrm{~cm}, 39.81 \mathrm{~cm}$ and 35.33 $\mathrm{cm})$ at all the stages. Similarly, maximum number of leaves per plant (214.07), number of internodes per stem (17.20) was observed in variety Rendez-vous $\left(\mathrm{V}_{4}\right)$. While, variety Gaudina $\left(\mathrm{V}_{1}\right)$ recorded significantly the highest internodal length $(12.26 \mathrm{~cm})$. Variety Liberty $\left(\mathrm{V}_{2}\right)$ recorded significantly the maximum number of auxiliary branches per plant (5.35). Significantly the highest stem length $(103.37 \mathrm{~cm})$, were observed in variety Farida $\left(\mathrm{V}_{3}\right)$.

KEY WORDS : Pinching, Internode, Stalk length

HOW TO CITE THIS ARTICLE : Singh, Sandeep, Karetha, K.M. and Singh, Virendra (2016). Effect of pinching on growth of carnation varieties grown under protected condition. Asian J. Hort., 11(1) : 119123, DOI : 10.15740/HAS/TAJH/11.1/119-123. 